\title{
Comparative study of antitumor effects of bromelain and papain in human cholangiocarcinoma cell lines
}

\author{
ALENA MÜLLER* , SAMARPITA BARAT* ${ }^{*}$ XI CHEN, KHAC CUONG BUI, \\ PRZEMYSLAW BOZKO, NISAR P. MALEK and RUBEN R. PLENTZ
}

\author{
Department of Internal Medicine I, Medical University Hospital, D-72076 Tübingen, Germany
}

Received December 22, 2015; Accepted February 3, 2016

DOI: $10.3892 /$ ijo.2016.3411

\begin{abstract}
Cholangiocarcinoma (CC) worldwide is the most common biliary malignancy with poor prognostic value and new systemic treatments are desirable. Plant extracts like bromelain and papain, which are cysteine proteases from the fruit pineapple and papaya, are known to have antitumor activities. Therefore, in this study for the first time we investigated the anticancer effect of bromelain and papain in intra- and extrahepatic human $\mathrm{CC}$ cell lines. The effect of bromelain and papain on human $\mathrm{CC}$ cell growth, migration, invasion and epithelial plasticity was analyzed using cell proliferation, wound healing, invasion and apoptosis assay, as well as western blotting. Bromelain and papain lead to a decrease in the proliferation, invasion and migration of $\mathrm{CC}$ cells. Both plant extracts inhibited NFKB/AMPK signalling as well as their downstream signalling proteins such as p-AKT, p-ERK, p-Stat3. Additionally, MMP9 and other epithelialmesenchymal-transition markers were partially found to be downregulated. Apoptosis was induced after bromelain and papain treatment. Interestingly, bromelain showed an overall more effective inhibition of $\mathrm{CC}$ as compared to papain. siRNA mediated silencing of $\mathrm{NF} \kappa \mathrm{B}$ on $\mathrm{CC}$ cells indicated that bromelain and papain have cytotoxic effects on human $\mathrm{CC}$ cell lines and bromelain and partially papain in comparison impair tumor growth by NFkB/AMPK signalling. Especially bromelain can evolve as promising, potential therapeutic option that might open new insights for the treatment of human $\mathrm{CC}$.
\end{abstract}

Correspondence to: Professor Ruben R. Plentz, Department of Internal Medicine I, Medical University Hospital, OtfriedMüller-Str. 10, D-72076 Tübingen, Germany

E-mail: ruben.plentz@med.uni-tuebingen.de

${ }^{*}$ Contributed equally

Abbreviations: CC, cholangiocarcinoma; EMT, epithelial-mesenchymal transition

Key words: antitumor therapy, bromelain, cholangiocarcinoma, papain

\section{Introduction}

Cholangiocarcinoma (CC) is a primary liver tumor arising from the epithelial cells lining the intra- and extrahepatic biliary tract system $(1,2)$. The incidence and mortality rate of $\mathrm{CC}$ are increasing worldwide and they represent the second most common primary hepatobiliary cancer $(3,4)$. Surgery is the only curative therapy, but $\mathrm{CC}$ is often diagnosed in advanced tumor stage $(4,5)$. Currently, the combination of gemcitabine and cisplatin is the standard chemotherapy for patients undergoing first line palliative treatment (6). Many cytotoxic compounds failed to improve therapy and new antitumor treatments are urgently needed to improve survival.

Bromelain is an extract of pineapple (Ananas comosus) and contains a mixture of proteases and non-protease components (7). Bromelain is sold in health food stores as a nutritional supplement to promote digestion, wound healing and as an anti-inflammatory agent (8). Oral treatment is well tolerated and there is traditional and anecdotal evidence that bromelain has different properties (7-10). Obviously, bromelain was tested in different experimental and clinical studies and it was demonstrated that this plant food has anticancer and anti-inflammatory activities (7,10-26). However, the precise molecular mechanisms are not fully understood.

Papain is a sulfhydryl protease from Carica papaya latex with a powerful digestive action superior to pancreatin, or pancreatic enzymes (27). Papain has high concentration in the fruit, stem, leaves, fruit skin and seeds. The compound has toxic effects on plant-eating bugs, supported wound healing and the juice of ripe papaya shows anti-oxidant effect (28-30). Papain is a known ingredient of herbal medicine in different countries, but there is very limited information on the molecular targets and anticancer effects. Ground-breaking studies for both compounds as anticancer therapies for CC are lacking so far. Using a model of human CC cell lines, we investigated for the first time the antitumor activity of both bromelain and papain on $\mathrm{CC}$.

\section{Materials and methods}

Cell culture. Human CC cell lines (TFK-1, SZ-1) were generously provided by Nisar Malek (31). Cell lines were cultured in RPMI-1640 + Glutamax (Invitrogen, Karlsruhe, Germany) supplemented with 10\% FCS (Biochrom, Berlin, Germany) 
and $100 \mathrm{U} / \mathrm{ml}$ penicillin/streptomycin (Invitrogen) at $37^{\circ} \mathrm{C}$ in $5 \% \mathrm{CO}_{2}$.

Compound preparation and in vitro treatment. Bromelain (Sigma-Aldrich, Germany - $25 \mathrm{mg}, 100 \mathrm{mM}$ ) stock solutions were prepared by dissolving them in dimethyl sulfoxide, DMSO (Applichem, Darmstadt, Germany). Papain (Sigma-Aldrich, $100 \mathrm{mM}$ ) stock solutions were prepared by dissolving them in distilled water. Cells were treated with DMSO or bromelain (150 and $200 \mu \mathrm{M})$ or papain $(25,40$ and $100 \mu \mathrm{M})$ in different concentrations $(100 \mathrm{mM})$ and were analyzed after 24,48 and $96 \mathrm{~h}$.

Proliferation assay. In order to measure the effect of bromelain and papain on cell proliferation, cells were plated at a concentration of 2,000 cells $/ \mathrm{ml}$ in a 96 -well plate overnight. Cells were treated with DMSO, different concentrations of bromelain $(150$ and $200 \mu \mathrm{M})$ or papain $(25,40$ and $100 \mu \mathrm{M})$ for different time-points (1-4 days). At the respective time-points, $10 \mu \mathrm{l}$ WST-1 reagent (Roche Diagnostics, Mannheim, Germany) was added to each well and incubated for $2 \mathrm{~h}$ at $37^{\circ} \mathrm{C}$. The absorbance was detected at a wavelength of $492 \mathrm{~nm}$ with reference wavelength of $650 \mathrm{~nm}$.

Invasion assay. Cells $\left(2.5 \times 10^{5}\right.$ cells $\left./ 2 \mathrm{ml}\right)$ were seeded in serum-free media into each well of the 6-well BD BioCoat ${ }^{\mathrm{TM}}$ Matrigel $^{\mathrm{TM}}$ Invasion Chamber (BD Biosciences, Bedford, UK). The cells in the inserts were simultaneously treated with bromelain $(150$ and $200 \mu \mathrm{M})$ or papain $(25,40$ and $100 \mu \mathrm{M})$ and the DMSO control. The inserts were placed into the BD Falcon TC Companion Plate containing 10\% FCS and incubated for $48 \mathrm{~h}$ in a humidified tissue culture incubator, at $37^{\circ} \mathrm{C}, 5 \% \mathrm{CO}_{2}$ atmosphere. Then the invading cells were fixed with $100 \%$ methanol and stained with $1 \%$ toluidine blue in $1 \%$ borax. Cells were then counted under a microscope (Leica DM 5000 B, Leica, Wetzlar, Germany). The calculation of the invading cells were done according to the $\mathrm{BD}$ protocol where:

$$
\text { Invasion index }=\frac{\% \text { invasion test cell }}{\% \text { invasion control cell }}
$$

Migration assay. Cells were seeded in a 6-well plate and left to reach $80 \%$ confluency. Initially, cells were starved for $24 \mathrm{~h}$ in media containing $2 \%$ FCS. Then SZ-1 and TFK-1 were further incubated for $48 \mathrm{~h}$ in the starvation media containing either the control with DMSO, different concentrations of bromelain (150 and $200 \mu \mathrm{M})$ or papain $(25,40$ and $100 \mu \mathrm{M})$. Afterwards a scratch was done using a white tip for each treatment. Then cells were washed with PBS and photographed using Leica DMI 6000 B microscope (Leica, Wetzlar, Germany). Cells were incubated for an additional $24 \mathrm{~h}$ after which the images were taken of the wounded area. The migrating cells were calculated according to the following formula:

Migration index $=\frac{\text { Width of the wound at } 0 \mathrm{~h}-\text { width of the wound at } 24 \mathrm{~h}}{} \times 100$

Width of the wound

Protein extraction and western blotting. SZ-1 and TFK-1 cells cultured with bromelain or papain treatment for immuno- blots were collected and rinsed with cold phosphate-buffered saline (PBS). Then harvested cells were lysed in lysis buffer containing $20 \mathrm{mM}$ Tris, $150 \mathrm{mM} \mathrm{NaCl}, 1 \mathrm{mM}$ EDTA, $1 \mathrm{mM}$ EGTA, 1\% Triton X-100 and protease and phosphatase inhibitor (Protease Inhibitor Cocktail Tablets, Roche, Mannheim, Germany). The concentration of extracted protein was determined using DC protein assay kit (Bio-Rad, München, Germany) according to the manufacturer's instructions. The absorption was measured at 650-750 nm using a microplate reader (Titertek-Berthold, Pforzheim, Germany). For immune blotting the cell lysates were loaded at a protein concentration of $30 \mu \mathrm{g}$ per well. Gel electrophoresis (12\% acrylamide gels) was performed (Bio-Rad, München, Germany). The membranes were blocked using 5\% dried milk (Applichem) for $30 \mathrm{~min}$ at room temperature, then they were probed with primary antibodies against E-cadherin (1:1,000, Cell Signaling Technology, 24E10), N-cadherin (2:10,000; Millipore, EPR1792Y), actin (2:10,000; Sigma, AC-74), Akt (1:1,000; Cell Signaling Technology, 4691), p-Akt (Ser473) (1:1,000; Cell Signaling Technology, 9271s), STAT3 (1:1,000; Cell Signaling Technology, 9132), p-Stat3 (Tyr705) (1:1,000; Cell Signaling Technology, 9131s), Rac-1 (1:000; Cytoskeleton, Inc., ARC03-A), PARP (1:1,000; Cell Signaling Technology, 9542), p44/p42 MAPK (Erk1/2) (1:1,000; Cell Signaling Technology, 4685s), phospho-p44/p42 MAPK (Erk1/2) (1:1,000; Cell Signaling Technology, 9101), AMPK $\alpha$ (D5A2) (1:500, Cell Signaling Technology, 5831S), phospho-AMPKa (1:500, Cell Signaling Technology, 2535S), NFкB p65 (1:1,000; Abcam, ab16502).

Small interfering RNA (siRNA) knockdown of $N F \kappa B$. SZ-1 and TFK-1 cells were plated at a concentration of $1 \times 10^{4}$ cells $/ \mathrm{ml}$ in a 6-well plate. After $24 \mathrm{~h}$, cells were transfected with control siRNA-A (Santa Cruz Biotechnology, CA, USA) 5, 10 and 20 nM NFkB siRNA (Santa Cruz Biotechnology, sc-29410) using hiperfect transfection reagent (Qiagen, Germany) for $48 \mathrm{~h}$. Trial experiments were performed with different concentrations of siRNA oligonucleotides at different time-points. The transfection efficiency was judged based on western blot analysis of $\mathrm{NF \kappa B}$.

Apoptosis. To determine the apoptosis, SZ-1 and TFK-1 cells were seeded $\left(1 \times 10^{4} / \mathrm{ml}\right)$ in 6 -well plate and were further treated under the same conditions described for WST-1 assay. After the respective treatments, floating cells were collected and adherent cells were trypsinized, washed twice with ice-cold PBS. The cells were then resuspended in $1 \mathrm{ml}$ of $1 \mathrm{X}$ binding buffer and were stained with Annexin V-FITC and PI according to the manufacturer's instructions using Annexin V Apoptosis Detection Kit II (BD Biosciences, San Diego, CA, USA). The signal was detected using LSRFortessa flow cytometer (Becton-Dickinson, USA) and analyzed using FlowJo Version 8.7 software (Tree Star Inc., Ashland, OR, USA).

Statistical analysis. All the experiments were repeated 3 times. The results were analyzed using software Graphpad prism version 5.0 (GraphPad Software, San Diego, CA, USA) and SPSS Version 11.0 (SPSS, Chicago, IL, USA). The tests include one way ANNOVA analysis of variance and Student's 
A

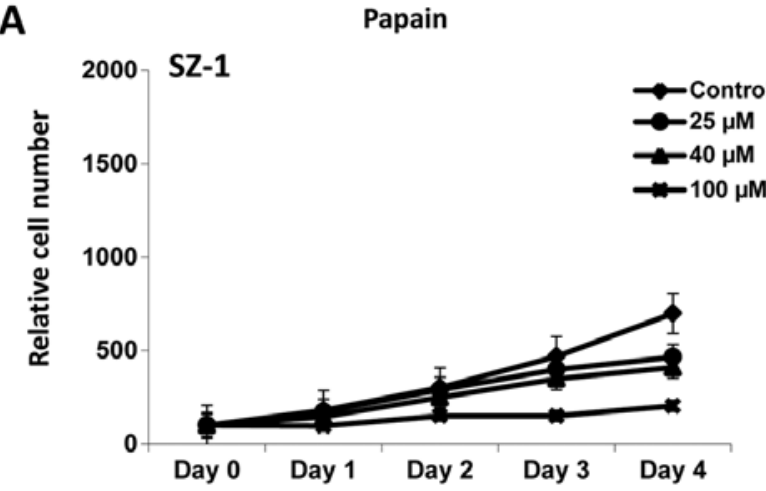

B

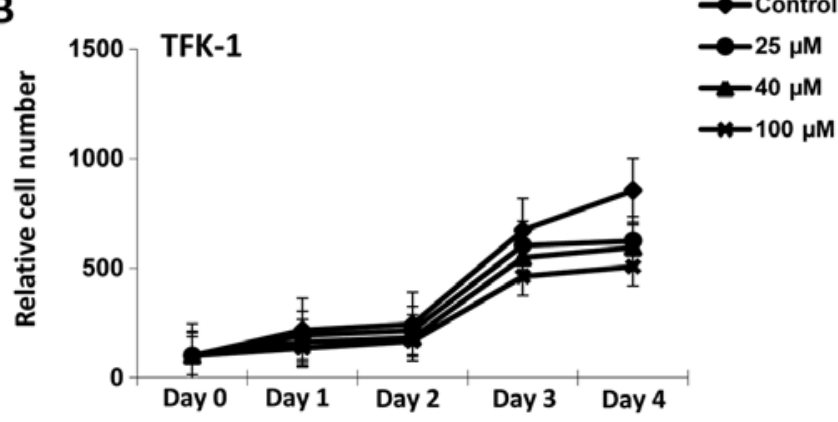

C

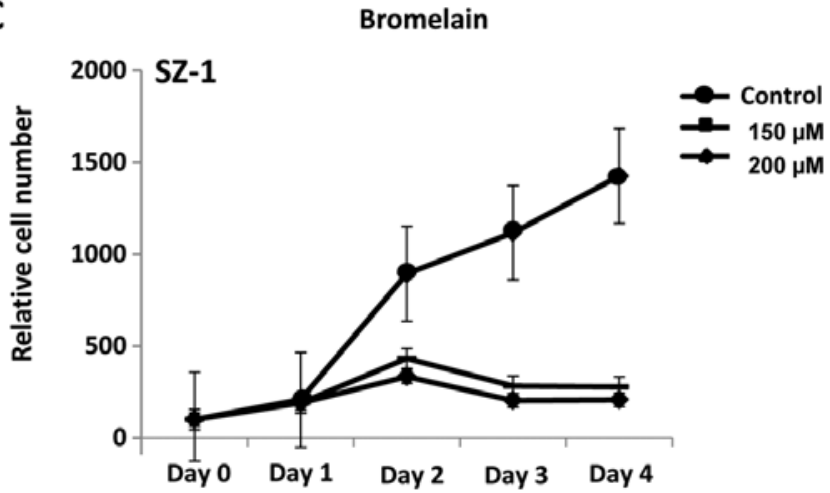

D

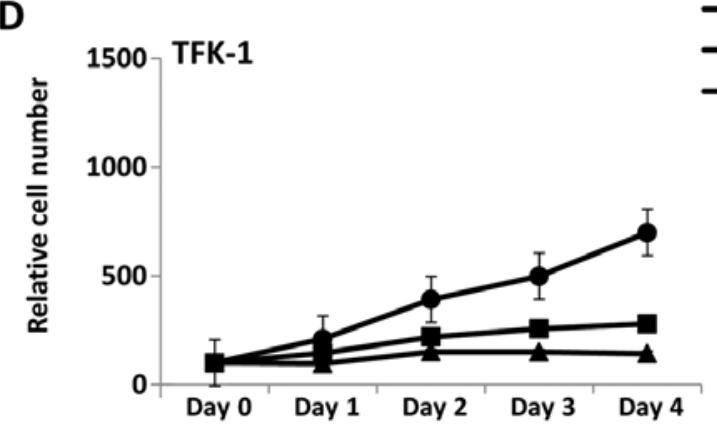

Figure 1. Effect of bromelain and papain on CC cell proliferation. SZ-1 (A and C) and TFK-1 (B and D) cells were treated by bromelain (150 and $200 \mu \mathrm{M}$ ), papain $(25,40$ and $100 \mu \mathrm{M})$, and their controls (DMSO, $\left.\mathrm{H}_{2} \mathrm{O}\right)$ as indicated. Cell proliferation was measured by WST assay. Both plant extracts inhibited cell proliferation in a dose- and time-dependent manner compared to their control.

t-test along with Bonferroni post test and paired and unpaired t-tests. Differences were considered as statistically significant when the P-value was $<0.05,<0.005$ and $<0.001$; and not significant (ns).

\section{Results}

Bromelain and papain attenuates the viability of CC cells. To analyze the anti-proliferative potential of bromelain and papain on TFK-1 and SZ-1 cells we determined first the $\mathrm{IC}_{50}$ value for papain by constructing a dose-response growth curve and examined the effect of different concentrations of papain on $\mathrm{CC}$ cells. Taking into account the calculated $\mathrm{IC}_{50}$, papain was used in three concentrations: 25,40 and $100 \mu \mathrm{M}$ (Fig. 1A and B). For bromelain therapy the previously published $\mathrm{IC}_{50}$ values were taken into account and dosage of 150 and $200 \mu \mathrm{M}$ were used $(25,26)$ (Fig. 1C and D). As shown (Fig. 1) both bromelain and papain treatment effectively decreases the proliferation of viable CC cells for $24,48,72$ and $96 \mathrm{~h}$. The highest anti-proliferative effect for both bromelain and papain was observed at $96 \mathrm{~h}$ under highest dosages (200 and $100 \mu \mathrm{M}$ for bromelain and papain, respectively).

Bromelain and papain treatment inhibits migration and invasion of CC cells. We next examined the effect of bromelain (150 and $200 \mu \mathrm{M})$ and papain $(25,40$ and $100 \mu \mathrm{M})$ on cell motility by wound healing assays (Fig. 2). All treatments and experiments were conducted as described in Materials and methods. Papain treatment $(25,40$ and $100 \mu \mathrm{M})$ showed considerable inhibition of wound healing especially in TFK-1 cells in comparison to SZ-1 cells (Fig. 2A-C). The highest inhibition effect was observed by papain in TFK-1 cells under $100 \mu \mathrm{M}$ treatment. Effective $(\mathrm{p}<0.05)$ inhibition of wound healing was observed under 150 and $200 \mu \mathrm{M}$ bromelain in both CC cells as compared to the DMSO controls (Fig. 2D-F). Next, we tested cell invasion using Matrigel-coated Transwell chambers under DMSO and bromelain (150 and $200 \mu \mathrm{M})$ and papain (25, 40 and $100 \mu \mathrm{M})$ (Fig. 3). As shown (Fig. 3B, $\mathrm{D}$ and $\mathrm{F}$ ), bromelain inhibited significantly cell invasion in a dose-dependent manner. Approximately $90 \%$ decrease in the number of invading cells was observed compared to the control group. Papain also showed similar effective inhibition of invasion in both CC cells compared to the control (Fig. 3A, $\mathrm{C}$ and $\mathrm{E})$.

Bromelain and papain treatment induces apoptosis in $C C$ cells. In order to elucidate that the anti-proliferative effect of both compounds (bromelain and papain) the induction of apoptosis, Annexin V/PI staining was performed and the percentage of apoptotic cells was determined by FACS analysis (Fig. 4). The results clearly showed that bromelain treatment induces relatively high rate of apoptosis on TFK-1 and SZ-1 cells in a time- and dose-dependent manner (Fig. 4C and D). The maximum induction was observed for bromelain for both CC cell lines at $96 \mathrm{~h}$ under $200-\mu \mathrm{M}$ treatment reaching $65-70 \%$ (Fig. 4C and D). Whereas for papain a similar pattern was observed, but the rate of induction was slightly lower compared to bromelain being $45-50 \%$ for both CC cell lines under $100 \mu \mathrm{M}$ of papain treatment at $96 \mathrm{~h}$ (Fig. 4A and B). We also showed a time-dependent increase of the protein poly 
A

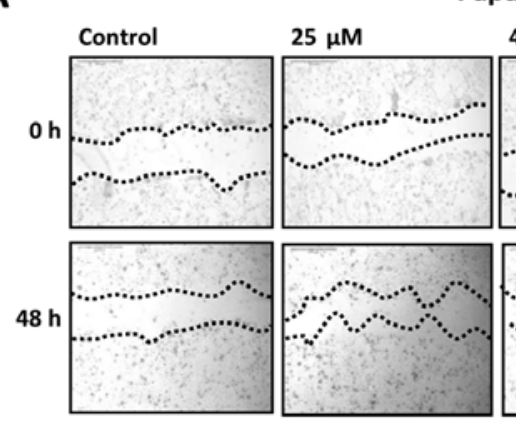

B

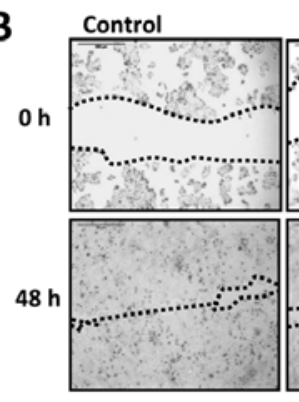

C

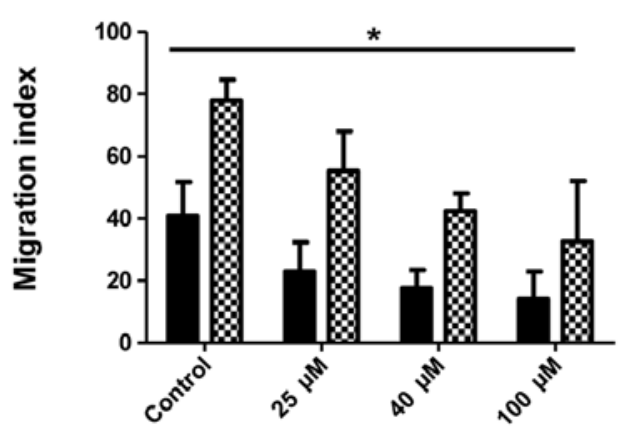

D

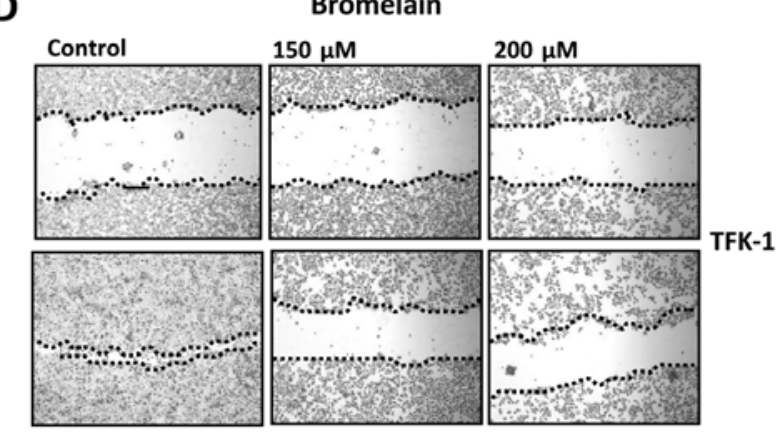

E

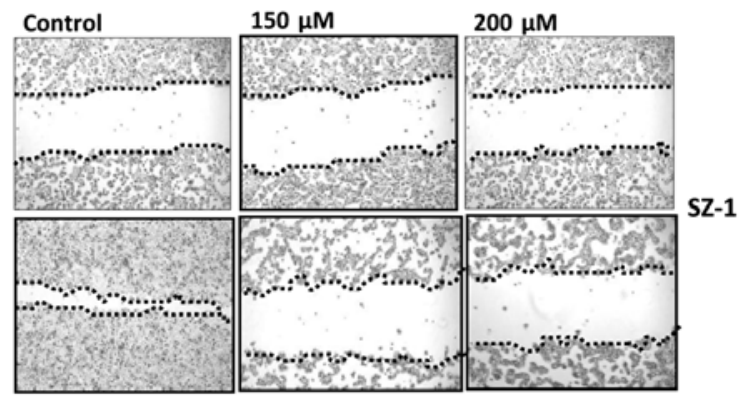

$\mathbf{F}$

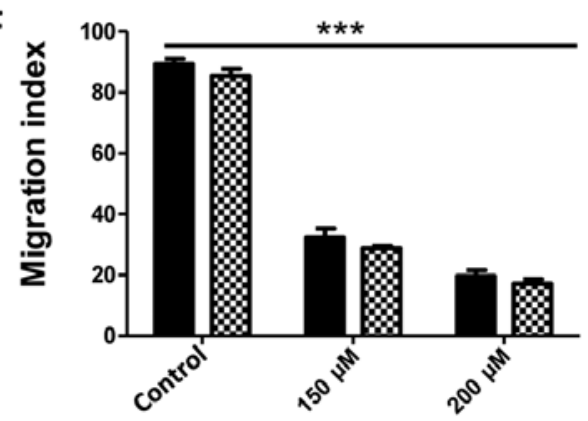

Figure 2. Bromelain and papain inhibits migration of CC cells. SZ-1 (B and E) and TFK-1 (A and D) cells were cultured with bromelain (150 and $200 \mu \mathrm{M}$ ), papain $\left(25,40\right.$ and $100 \mu \mathrm{M}$ ), or their controls (DMSO, $\mathrm{H}_{2} \mathrm{O}$ ). A scratch was made at (time $0 \mathrm{~h}$ ) in both SZ1 and TFK1 and maintained for $24 \mathrm{~h}$ in conditioned medium with bromelain, papain, or their controls (DMSO, $\mathrm{H}_{2} \mathrm{O}$ ). The dotted lines represent the edges of the wound. Images were taken under a light microscope (x10 magnification). The migration index was calculated as described in Materials and methods and plotted in bar graphs (C and F). Data are expressed as mean $\pm \mathrm{SD}$ of triplicates. Differences were considered as statistically significant at ${ }^{*} \mathrm{P}<0.05$ and ${ }^{* * *} \mathrm{P}<0.001$.

(adenosine diphosphate ribose) polymerase (PARP) cleavage after bromelain and papain treatment for SZ-1 and TFK-1 cells (Fig. 4). The results are in accord with the findings of the cell proliferation assay. Thus, our results show that bromelain and papain both induced considerable amount of apoptosis on CC cells.

Bromelain effectively inhibits $N F \kappa B / A M P K$ pathway and common downstream effectors in CC cells in contrast to papain. NFKB/AMPK signaling has been implicated as an important pathway involved in the carcinogenesis of several tumor diseases (32). In order to gain more insight into the anticancer mechanism exerted by both bromelain and papain in $\mathrm{CC}$ cells, we checked the status of AMPK and $\mathrm{NF \kappa B}$ both before and after treatment by immunoblotting. In both cell lines (TFK-1, SZ-1) bromelain (150 and $200 \mu \mathrm{M})$ effectively downregulated $\mathrm{NF \kappa B}$ and other common downstream proteins such as phospho-AKT, phospho-ERK and phosphoSTAT3, but the full forms remained unchanged in both cell lines for 48 and $96 \mathrm{~h}$ (Fig. 5). An effective upregulation of phospho-AMPK was observed under bromelain treatment for both time-points in a time- and dose-dependent manner (Fig. 5C and D). Thus, clearly indicating effective inhibition of the NFKB/AMPK pathway in CC cells by bromelain. In contrast, papain treatment $(25,40$ and $100 \mu \mathrm{M})$ did not show effective downregulation of $\mathrm{NF \kappa B}$ in either $\mathrm{CC}$ cell line (Fig. 5A and B). For SZ-1 cells under papain treatment full and phosphorylated forms of ERK, STAT3 remained unchanged for all tested time-points (Fig. 5B). In contrast, AKT full form remained unchanged but the phosphorylated form showed slight downregulation in SZ-1 under $100 \mu \mathrm{M}$ of papain treatment specifically in $96 \mathrm{~h}$ (Fig. 5B). In TFK-1 cells papain treatment effectively downregulated phospho-STAT3 in all dosages $(25,40$ and $100 \mu \mathrm{M})$ specifically after $96 \mathrm{~h}$ (Fig. 5A). Full forms of other effector proteins like AKT, ERK, STAT3 remained stable under papain treatment but the phosphorylated forms were slightly downregulated mostly under $100 \mu \mathrm{M}$ of treatment at $96 \mathrm{~h}$ (Fig. 5A and B). Interestingly, NFKB and AMPK levels remained mostly unaltered under papain treatment for both CC cell lines for all time-points compared to the respective controls. Moreover, phosphorylated AMPK showed considerable upregulation in SZ-1 cells under $100 \mu \mathrm{M}$ of 
A
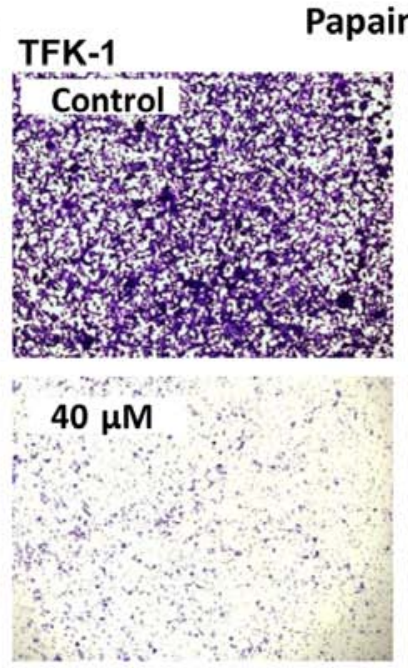

C sz-1
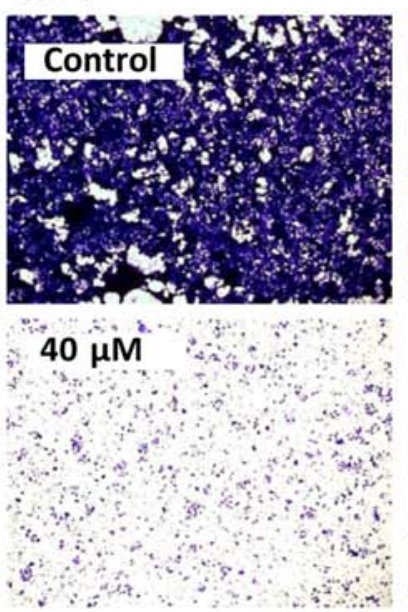

E

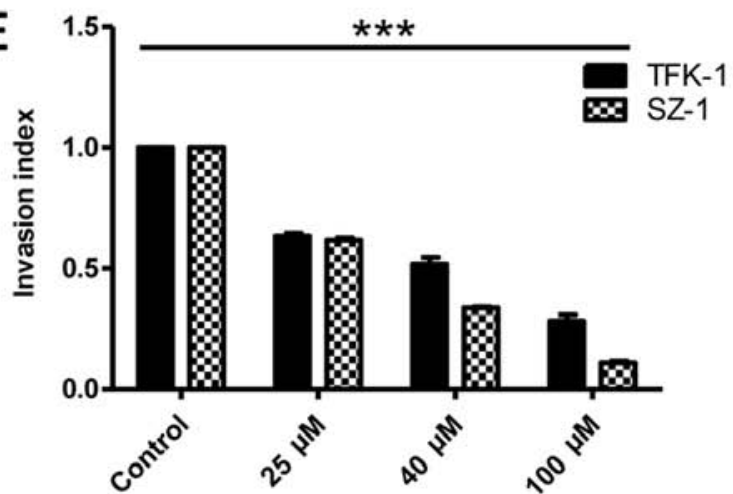

B
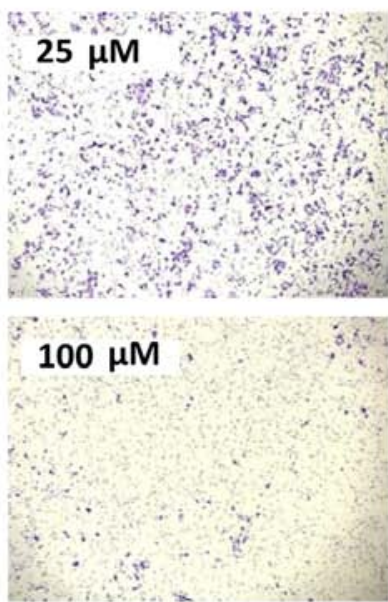

\section{D sz-1}

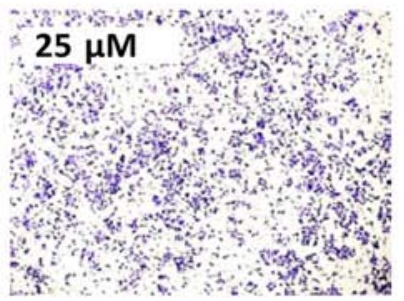

$100 \mu \mathrm{M}$
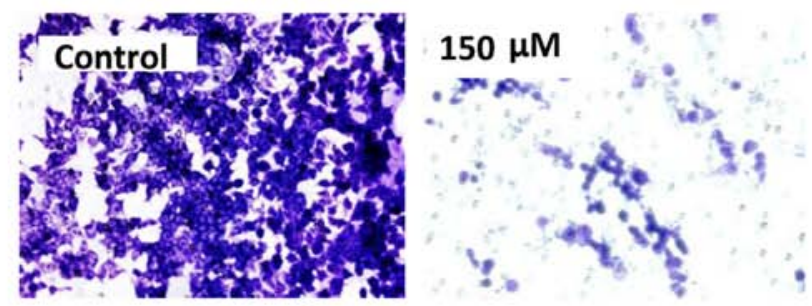

$200 \mu \mathrm{M}$
Bromelain

TFK-1

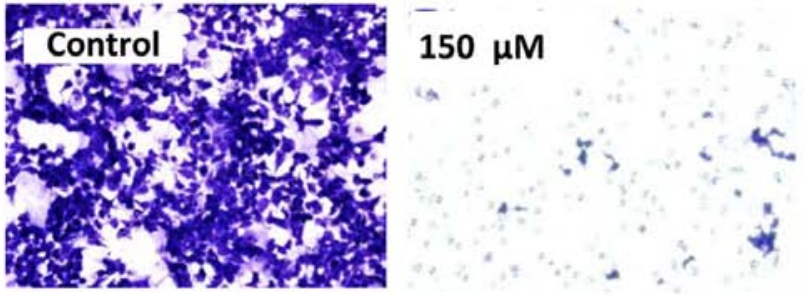

$200 \mu \mathrm{M}$

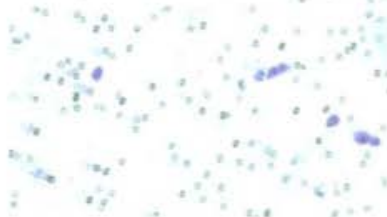

F

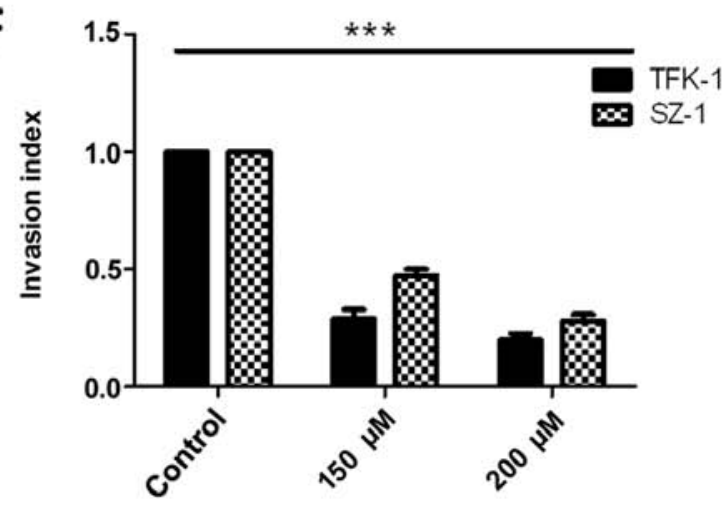

Figure 3. Bromelain and papain inhibits invasion of CC cells. SZ-1 (C-F) and TFK-1 (A, B, E and F) cells were treated for $48 \mathrm{~h}$ with bromelain (150 and $200 \mu \mathrm{M}$ ), papain $\left(25,40\right.$ and $100 \mu \mathrm{M}$ ), or their controls (DMSO, $\mathrm{H}_{2} \mathrm{O}$ ). The number of cells that invaded through the membrane was determined by light microscope (x20 magnification) counterstained and invasion index was calculated as described in Materials and methods and plotted in bar graphs. Differences were statistically significant at ${ }^{* * *} \mathrm{P}<0.001$. Data are expressed as mean $\pm \mathrm{SD}$ of triplicates.

papain treatment for both time-points (48 and 96 h) (Fig. 5B). In TFK-1 cells slight upregulation of phosphorylated AMPK was observed in a dose-dependent manner of papain treament in comparison to the control (Fig. 5A). Thus, papain treatment partially influences, but does not inhibit NFאB/AMPK signaling in contrast to bromelain in CC cells.

We further reconfirmed the importance of $\mathrm{NF} \kappa \mathrm{B}$ status for bromelain anticancer activity in $\mathrm{CC}$ cells by $\mathrm{NF} \kappa \mathrm{B}$ siRNA.
NFאB silencing in both TFK-1 and SZ-1 cells showed effective inhibition of all the common downstream proteins, such as AKT and ERK, as shown in Fig. 6A and B. Importantly, $200 \mu \mathrm{M}$ of bromelain treatment achieved similar results of effective inhibition of all downstream effector proteins as that with NFKB siRNA for both tested CC cells. However, $100 \mu \mathrm{M}$ of papain treatment did not show effective inhibition of any of the above mentioned common downstream effector proteins 
A
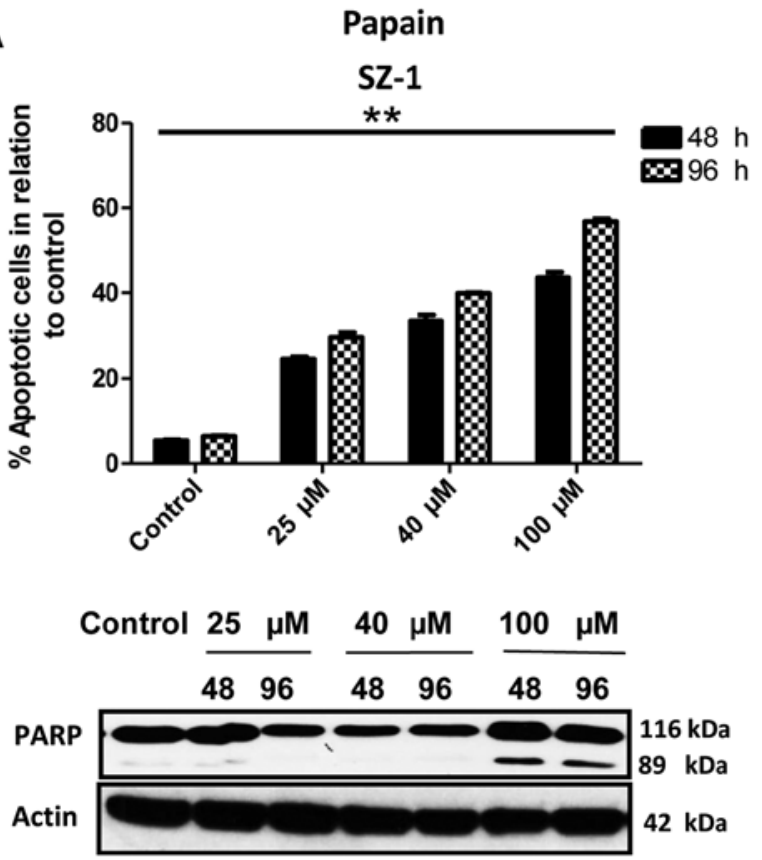

B
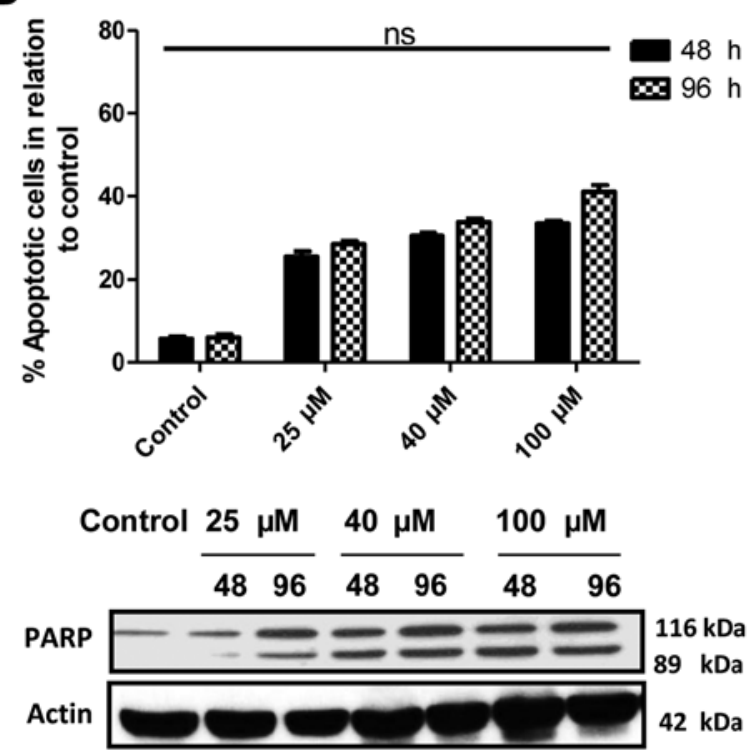

C
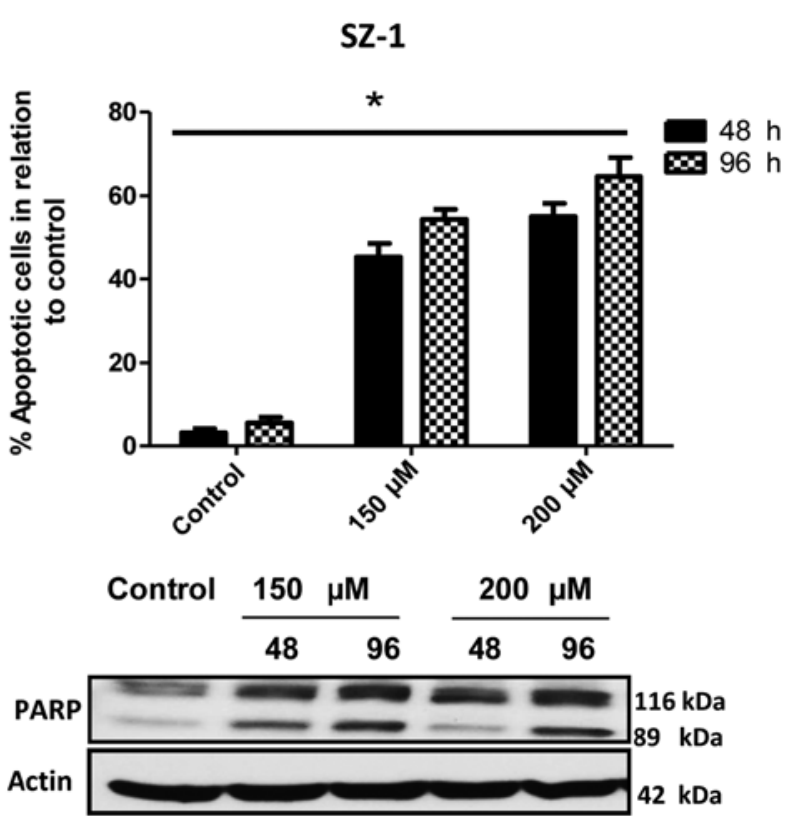

D

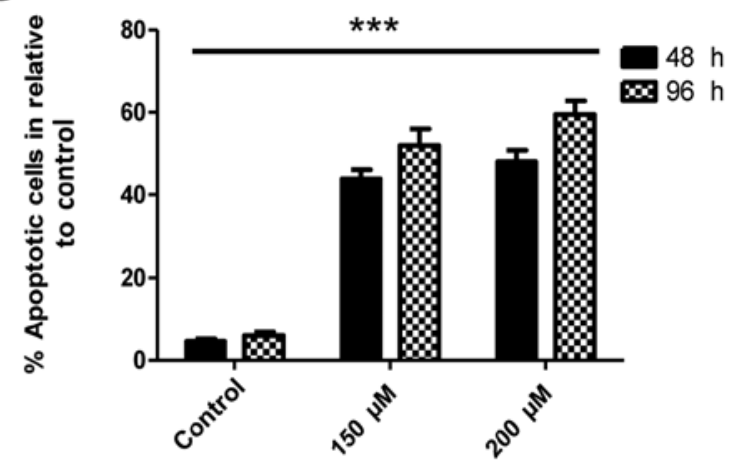

Control $\frac{150 \mu \mathrm{M}}{48 \quad 96} \quad \frac{200 \mu \mathrm{M}}{48 \quad 96}$

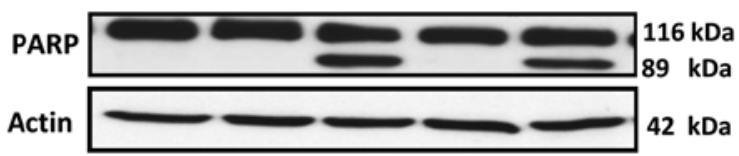

Figure 4. Apoptosis is induced by bromelain and papain. Annexin V staining detected the percentage of apoptotic cells after 48- and 96-h exposure to indicated concentrations of bromelain, papain or their controls of SZ-1 (A and C) and TFK-1 (B and D) cells. Differences were considered as statistically significant at ${ }^{*} \mathrm{P}<0.05,{ }^{* *} \mathrm{P}<0.005,{ }^{* * *} \mathrm{P}<0.001$; not significant (ns). Data are expressed as mean $\pm \mathrm{SD}$ of triplicates. Western blot analysis of PARP cleavage in treated SZ-1 (A and C) and TFK-1 (B and D) cells. The upper bands represent the full-length PARP (116 kDa); the lower bands represent the cleaved PARP product (89 kDa). Actin was used as a loading control.

in contrast to $\mathrm{NFKB}$ silencing compared to the controls for both CC cell lines (Fig. 6). Based on these results bromelain effectively impairs $\mathrm{CC}$ carcinogenesis via inhibition of $\mathrm{NF \kappa B} /$ AMPK signaling, but not papain.

Bromelain significantly impairs EMT in comparison to papain in CC cells. EMT is considered a key process driving invasion and metastasis. Therefore, we examined whether bromelain or papain can attenuate EMT. CC cells were treated with either bromelain (150 and $200 \mu \mathrm{M})$, papain $(25,40$ and $100 \mu \mathrm{M}$ ) or DMSO for 48 and $96 \mathrm{~h}$. The expression of EMT markers (E-cadherin and $\mathrm{N}$-cadherin) was evaluated by western blotting (Fig. 7). Bromelain treatment showed doseand time-dependent increase in expression of the epithelial marker E-cadherin (Fig. 7B and D) and downregulation of the mesenchymal marker N-cadherin both in TFK-1 and SZ-1 cells (Fig. 7B and D). Notably, the expression of both E- and $\mathrm{N}$-cadherin remained relatively unaltered under papain treatments $(25,40$ and $100 \mu \mathrm{M})$ in both CC cell lines for 48 and $96 \mathrm{~h}$ (Fig. 7A and C). Our immunoblots clearly show the effective inhibition of EMT by bromelain in contrast to papain, which shows no influence on EMT in human CC cells. 
A

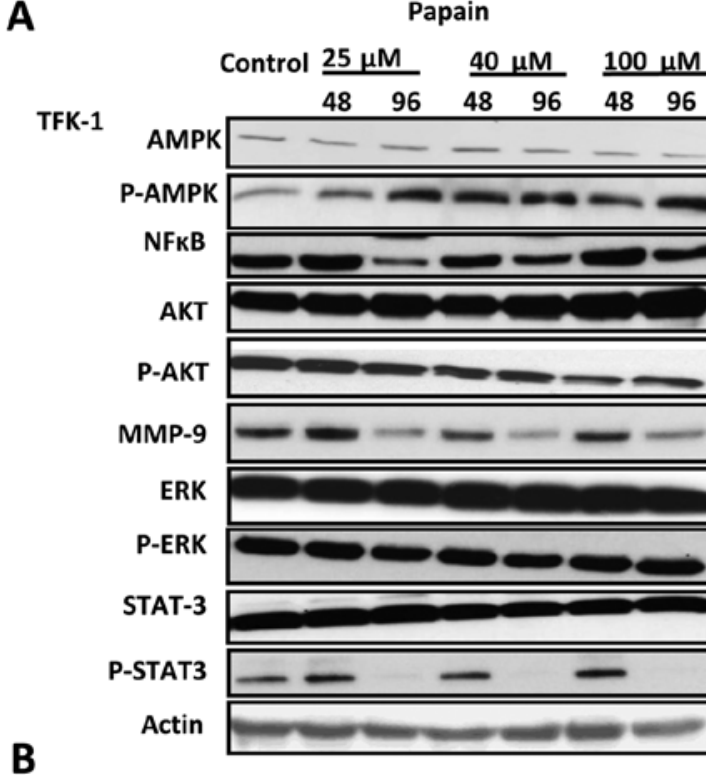

B

SZ-1

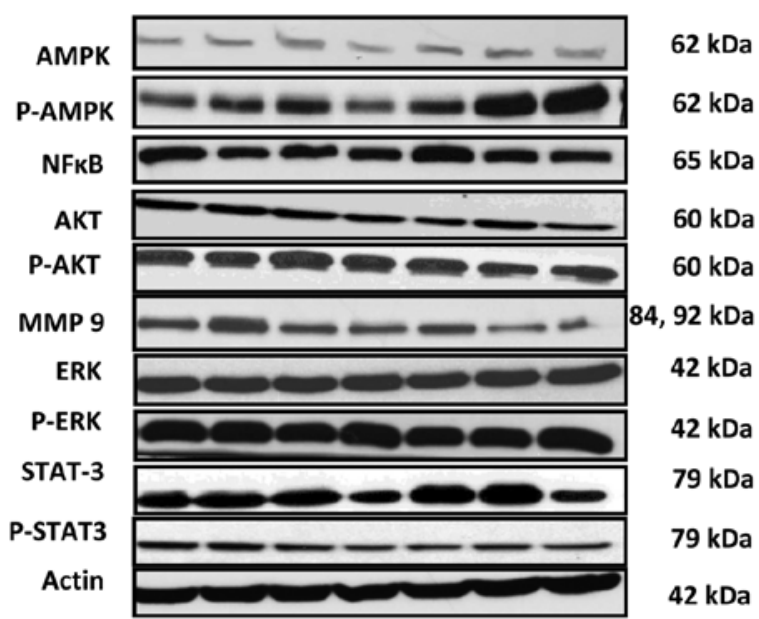

$62 \mathrm{kDa}$

$62 \mathrm{kDa}$

$65 \mathrm{kDa}$

$60 \mathrm{kDa}$

$60 \mathrm{kDa}$

$84,92 \mathrm{kDa}$

$42 \mathrm{kDa}$

$42 \mathrm{kDa}$

$79 \mathrm{kDa}$

$79 \mathrm{kDa}$

$42 \mathrm{kDa}$
C

\section{D}

SZ-1

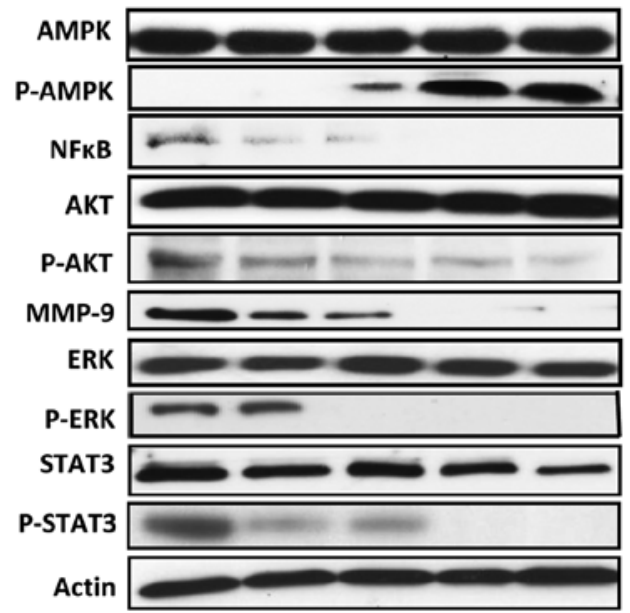

$62 \mathrm{kDa}$

$62 \mathrm{kDa}$

$65 \mathrm{kDa}$

$60 \mathrm{kDa}$

$60 \mathrm{kDa}$

$84,92 \mathrm{kDa}$

$42 \mathrm{kDa}$

$42 \mathrm{kDa}$

$79 \mathrm{kDa}$

$79 \mathrm{kDa}$

$42 \mathrm{kDa}$

$62 \mathrm{kDa}$

$62 \mathrm{kDa}$

$65 \mathrm{kDa}$

$60 \mathrm{kDa}$

$60 \mathrm{kDa}$

$84,92 \mathrm{kDa}$

$42 \mathrm{kDa}$

$42 \mathrm{kDa}$

$79 \mathrm{kDa}$

$79 \mathrm{kDa}$

$79 \mathrm{kDa}$

42 kDa

Figure 5. Impact of bromelain and papain on NFkB/AMPK signaling and their downstream targets. SZ-1 and TFK-1 cells were treated either with bromelain (C and D), papain (A and B) or their controls (DMSO, $\mathrm{H}_{2} \mathrm{O}$ ) with indicated concentrations $(25,40,100,150$ and $200 \mu \mathrm{M})$ for 48 and $96 \mathrm{~h}$ and cell lysates were analyzed by western blot analysis with antibodies against phosphorylated AMPK, AMPK, NFKB, phosphorylated AKT, AKT, phosphorylated ERK, ERK, phosphorylated STAT3 and STAT3. Actin was used as loading control. Note, papain application did not fully inihibit NFKB/AMPK signaling compared to the plant extract bromelain.

\section{Discussion}

Plant derived extracts such as bromelain and papain have been used for herbal medicine and are easy to acquire. However, the exact molecular modes of actions and therapeutic effects are not fully understood. So far, no trials have been conducted to test the efficacy of bromelain and papain in human CC. We hypothesised that both compounds might impair CC carcinogenesis and investigated their efficacy in inhibiting growth and proliferation of human CC cell lines (TFK-1, SZ-1). In this study, we found that bromelain and papain have potent antitumor activity against CC. We observed four major findings: i) anticancer effect of bromelain was more effective compared to papain, ii) significant restriction of $\mathrm{CC}$ cells was mainly achieved via inhibition of NFKB/AMPK pathway iii) therapy induced apoptosis, iv) EMT was only partially influenced. Importantly, in our experiments we used two human CC cell lines from different origins: TFK-1 cultured from an extrahe- patic primary tumor and SZ-1 cultured from an intrahepatic primary tumor (31).

Bromelain was tested in vitro and in vivo cancer models and it was demonstrated in a skin papilloma model that bromelain application reduced tumor formation by apoptotic cell death (33). It was also reported that bromelain influences metastasis, local tumor growth, cell growth and migration (16-19). Furthermore, it is known that bromelain can downregulate $\mathrm{NF \kappa B}$ and Cox-regression in papillomas and skin cancer (34). For papain it is known that anti-angiogenic effects are accessible (35). In addition, papain has anti-inflammatory, anti-infectious and anti-diabetic characteristics (36). We found that both plant extracts significantly suppressed CC growth, influencing cell migration and invasion. Since bromelain was also previously tested for anticancer ability in other tumor models as described above we selected two widely used and established dosages $(150$ and $200 \mu \mathrm{M})(25,26)$. Our experiments on CC cells also reconfirmed these two pre-established 


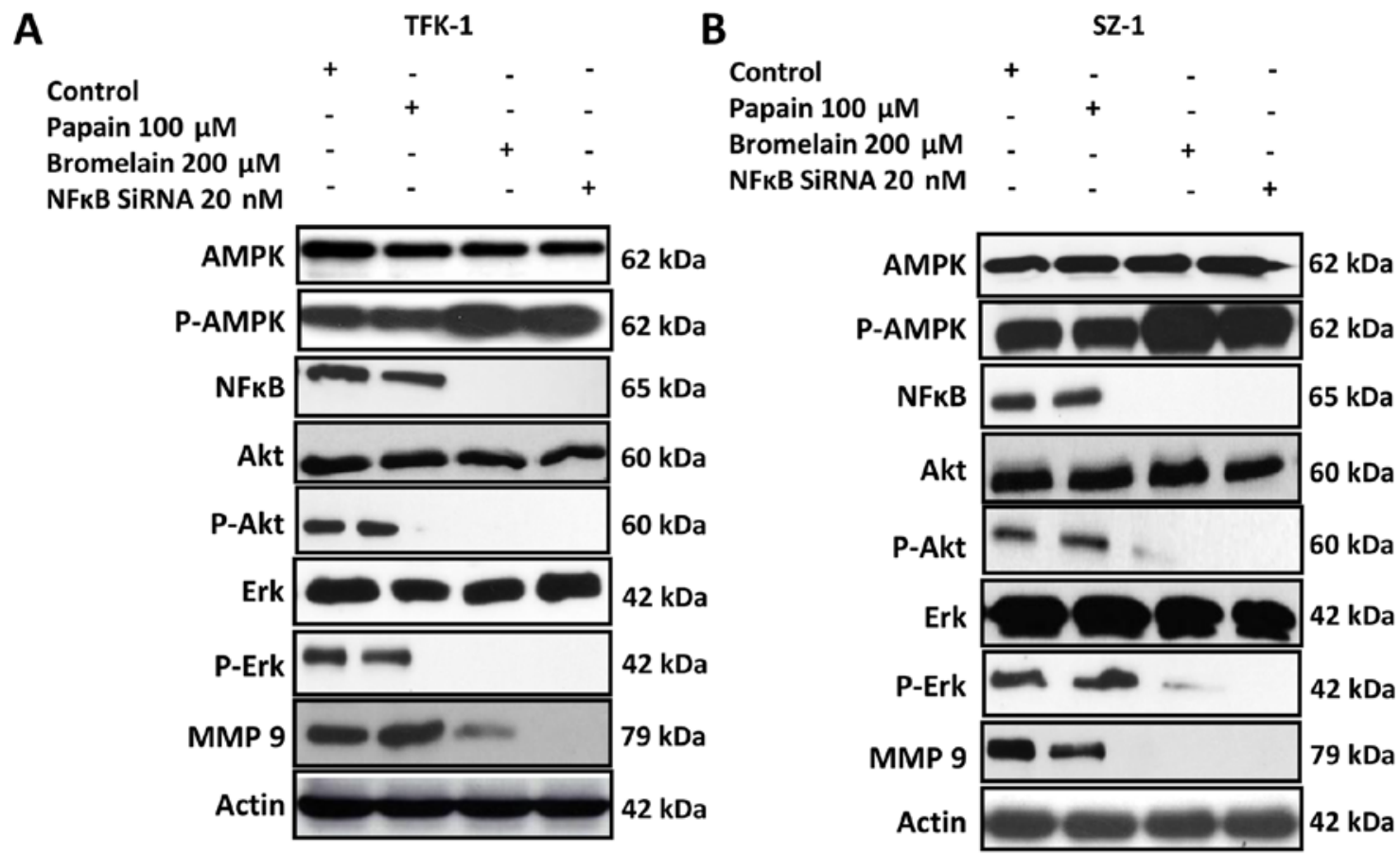

Figure 6. Effects of NFKB siRNA treatment on CC cells. Comparison of bromelain, papain, DMSO, $\mathrm{H}_{2} \mathrm{O}$ treatments as well as silencing of NFkB in TFK-1 (A) and SZ-1 (B) cells. Cells were transfected with $20 \mathrm{nM} \mathrm{NF \kappa B} \mathrm{SiRNA}$ or with control siRNA $(20 \mathrm{nM})$. Cell lysates were analyzed by western blot analysis with antibodies against phosphorylated AMPK, AMPK, NFKB, phosphorylated AKT, AKT, phosphorylated ERK, ERK and MMP9. Actin was used as loading control. Note, only bromelain influences significantly the NFKB/AMPK signaling compared to papain.
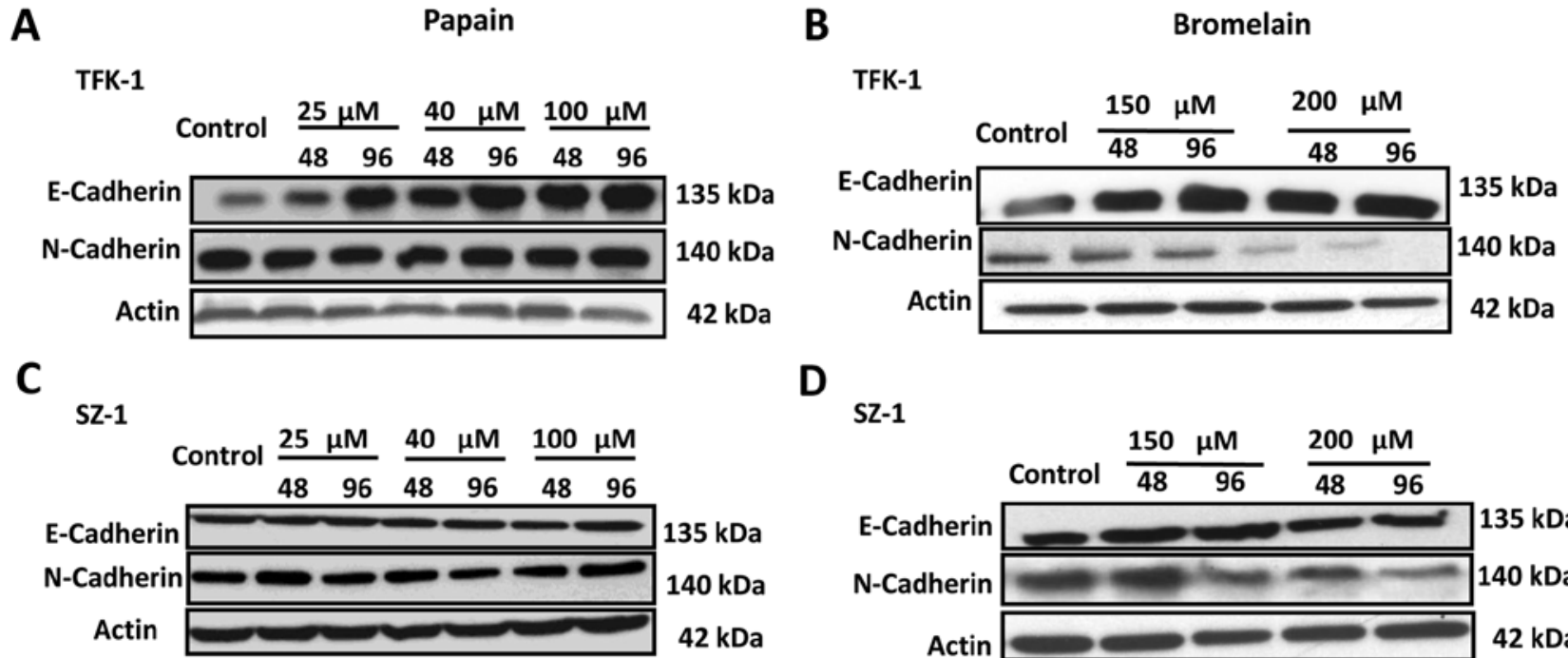

D

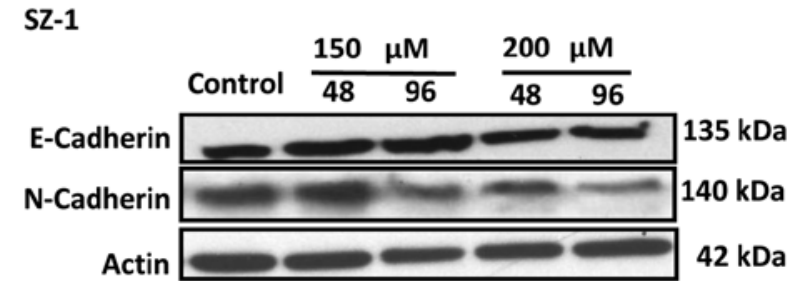

Figure 7. Changes of EMT expression in bromelain and papain treated CC cells. SZ-1 and TFK-1 cells were treated either with bromelain (B and D), papain (A and C) or their controls (DMSO, $\mathrm{H}_{2} \mathrm{O}$ ) with indicated concentrations $(25,40,100,150$ and $200 \mu \mathrm{M}$ ) for 48 and $96 \mathrm{~h}$ and cell lysates were analyzed by western blot analysis with antibodies against E-cadherin and $\mathrm{N}$-cadherin. Actin was used as loading control. Note, mainly bromelain has an influence on EMT compared to papain therapy.

dosages as the most effective ones for the inhibition studies in CC cells. Interestingly, papain has not been tested as an anticancer drug, therefore, in our study we for the first time performed $\mathrm{IC}_{50}$ experiments and selected three dosages that were found be suitable for CC cell inhibition. Notably, the dosages used for papain where comparatively lower than to bromelain mainly because we picked up three dosages for papain that covered a range from low to high $(25-100 \mu \mathrm{M})$.
Notably, $100 \mu \mathrm{M}$ of papain treatment failed to show effective downregulation of the common downstream proteins. This difference could possibly be due to the existance of some feedback loop with other cancer pathways in CC which in turn can upregulate or activate the common downstreams. Thus, reactivating the $\mathrm{CC}$ carcinogenesis process which was temporarily restricted by papain treatment. Papain treatment ceases or stops the proliferation of CC cells temporarily, but 
fails to effectively inhibit any cancer signaling cascade or their crosstalk involved in CC carcinogenesis. On the contrary, bromelain not only inhibits proliferation of CC cells but also effectively downregulates the common downstream proteins leading to complete inhibition of CC carcinogenesis mainly via the NFאB/AMPK signaling pathway.

Our results clearly showed that the degree of effectiveness of a plant extract greatly depends on the source, as papain even in higher dosages did not show effective inhibition of AMPK $\mathrm{NF} \kappa \mathrm{B}$ signaling. The cytotoxic effect of bromelain and papain seemed to be caused by apoptotic cell death. We tried to further elucidate the mechanisms by which the cysteine proteases affect CC cells and to understand the differences between the compounds. Therefore, we investigated the expression status of $\mathrm{NF \kappa B}$ and the phosphorylation status of AMPK on protein level. Bromelain treatment caused a significant decrease of $\mathrm{NF \kappa B}$ and increase in AMPK phosphorylation. In contrast, papain did not alter NFKB/AMPK signalling significantly. The $\mathrm{NF} \kappa \mathrm{B} / \mathrm{AMPK}$ signalling pathway is amongst others important for the immune system (37). Studies have demonstrated that AMPK signalling downregulates the function of NFKB (38).

We tested the status of NFKB and AMPK under treatment with bromelain and papain on $\mathrm{CC}$ cells by selective knockdown using siRNA and compared the results with bromelain/ papain single treatment on CC cells. We also further analyzed some important selective downstream effector proteins such as AKT, ERK and STAT3, known to be crucial for inhibition studies. Under treatment upregulation of phosphorylated AMPK was observed, thus, leading to the inhibition or effective downregulation of $\mathrm{NF} \mathrm{B}$ and the common downstream proteins phospho-AKT, ERK and STAT3. Moreover, studies indicated MMP9 as one of the key transcription factors for $\mathrm{NF} \kappa \mathrm{B}$-mediated inflammation and tumor invasion. Hence, under bromelain treatment effective $\mathrm{NF} \kappa \mathrm{B}$ inhibition also led to significant downregulation of MMP9 expression. Furthermore, siRNA mediated silencing of NFKB also reconfirmed our hypothesis that both plant extracts might exert their antitumor effects on $\mathrm{CC}$ cells via $\mathrm{NF \kappa B} / \mathrm{AMPK}$ signalling. Importantly, the difference in the overall treatment outcome between these two plant extracts can also be attributed to the inability of papain to effectively inhibit the NFKB/AMPK signalling in CC cells as compared to bromelain. Altogether, it can be highlighted that NFאB/AMPK signalling could be a probable mechanistic approach for antitumor activity of these two plant extracts (especially bromelain) in CC cells and the effectiveness of the compound as an anticancer agent depends on the ability to inhibit this pathway, bromelain and papain may also influence EMT, which is associated with carcinogenesis and metastasis of cancer (39). However, bromelain efficacy was different between the investigated CC cell lines. Some widely studied EMT markers such as N-cadherin and E-cadherin were strongly influenced in TFK-1 as compared to SZ-1 cells under treatment by both plant extracts. Under papain therapy EMT changes were less pronounced compared to bromelain, confirming the importance of NFKB/AMPK signalling and suggesting again that bromelain treatment is more effective as an anti-proliferative compound in CC.

Our data demonstrate that treatment by bromelain is superior to papain as a potential therapy for human $\mathrm{CC}$ and that the inhibition effect is mainly caused by impairment of $\mathrm{NF \kappa B} /$
AMPK signalling. Future studies with bromelain either as a single agent or in combination with other drugs are needed in order to investigate in detail the exact mechanistic approach of such plant extracts for $\mathrm{CC}$ treatment.

\section{References}

1. Gatto $M$ and Alvaro D: New insights on cholangiocarcinoma. World J Gastrointest Oncol 2: 136-145, 2010.

2. Welzel TM, McGlynn KA, Hsing AW, O'Brien TR and Pfeiffer RM: Impact of classification of hilar cholangiocarcinomas (Klatskin tumors) on the incidence of intra- and extrahepatic cholangiocarcinoma in the United States. J Natl Cancer Inst 98: 873-875, 2006.

3. von Hahn T, Ciesek S, Wegener G, Plentz RR, Weismüller TJ, Wedemeyer H, Manns MP, Greten TF and Malek NP: Epidemiological trends in incidence and mortality of hepatobiliary cancers in Germany. Scand J Gastroenterol 46: 1092-1098, 2011.

4. Shaib Y and El-Serag HB: The epidemiology of cholangiocarcinoma. Semin Liver Dis 24: 115-125, 2004.

5. Tyson GL and El-Serag HB: Risk factors for cholangiocarcinoma. Hepatology 54: 173-184, 2011.

6. Valle J, Wasan H, Palmer DH, Cunningham D, Anthoney A, Maraveyas A, Madhusudan S, Iveson T, Hughes S, Pereira SP, et al; ABC-02 Trial Investigators: Cisplatin plus gemcitabine versus gemcitabine for biliary tract cancer. N Engl J Med 362: 1273-1281, 2010.

7. Chobotova K, Vernallis AB and Majid FA: Bromelain's activity and potential as an anti-cancer agent: Current evidence and perspectives. Cancer Lett 290: 148-156, 2010.

8. Gruenwald J, Brendler T and Jaenicke C (eds): PDR for Herbal Medicines. 4th edition. Thomson Healthcare, Montvale, NJ, 2007.

9. Castell JV, Friedrich G, Kuhn CS and Poppe GE: Intestinal absorption of undegraded proteins in men: Presence of bromelain in plasma after oral intake. Am J Physiol 273: G139-G146, 1997.

10. Taussig SJ and Batkin S: Bromelain, the enzyme complex of pineapple (Ananas comosus) and its clinical application. An update. J Ethnopharmacol 22: 191-203, 1988.

11. Maurer HR: Bromelain: Biochemistry, pharmacology and medical use. Cell Mol Life Sci 58: 1234-1245, 2001.

12. Eckert K, Grabowska E, Stange R, Schneider U, Eschmann K and Maurer HR: Effects of oral bromelain administration on the impaired immunocytotoxicity of mononuclear cells from mammary tumor patients. Oncol Rep 6: 1191-1199, 1999.

13. Brien S, Lewith G, Walker AF, Middleton R, Prescott P and Bundy R: Bromelain as an adjunctive treatment for moderate-to-severe osteoarthritis of the knee: A randomized placebo-controlled pilot study. QJM 99: 841-850, 2006.

14. Guo R, Canter PH and Ernst E: Herbal medicines for the treatment of rhinosinusitis: A systematic review. Otolaryngol Head Neck Surg 135: 496-506, 2006.

15. Baumhackl U, Kappos L, Radue EW, Freitag P, Guseo A, Daumer $\mathrm{M}$ and Mertin J: A randomized, double-blind, placebocontrolled study of oral hydrolytic enzymes in relapsing multiple sclerosis. Mult Scler 11: 166-168, 2005.

16. Báez R, Lopes MT, Salas CE and Hernández M: In vivo antitumoral activity of stem pineapple (Ananas comosus) bromelain. Planta Med 73: 1377-1383, 2007.

17. Beuth J and Braun JM: Modulation of murine tumor growth and colonization by bromelaine, an extract of the pineapple plant (Ananas comosum L.). In Vivo 19: 483-485, 2005.

18. Guimarães-Ferreira CA, Rodrigues EG, Mortara RA, Cabral H, Serrano FA, Ribeiro-dos-Santos R and Travassos LR: Antitumor effects in vitro and in vivo and mechanisms of protection against melanoma B16F10-Nex 2 cells by fastuosain, a cysteine proteinase from Bromelia fastuosa. Neoplasia 9: 723-733, 2007.

19. Taussig SJ, Szekerczes J and Batkin S: Inhibition of tumour growth in vitro by bromelain, an extract of the pineapple plant (Ananas comosus). Planta Med 51: 538-539, 1985.

20. Tysnes BB, Maurer HR, Porwol T, Probst B, Bjerkvig R and Hoover F: Bromelain reversibly inhibits invasive properties of glioma cells. Neoplasia 3: 469-479, 2001.

21. Bhui K, Tyagi S, Srivastava AK, Singh M, Roy P, Singh R and Shukla Y: Bromelain inhibits nuclear factor kappa-B translocation, driving human epidermoid carcinoma A431 and melanoma A375 cells through $\mathrm{G}(2) / \mathrm{M}$ arrest to apoptosis. Mol Carcinog 51: 231-243, 2012. 
22. Romano B, Fasolino I, Pagano E, Capasso R, Pace S, De Rosa G, Milic N, Orlando P, Izzo A A and Borrelli F: The chemopreventive action of bromelain, from pineapple stem (Ananas comosus L.), on colon carcinogenesis is related to antiproliferative and proapoptotic effects. Mol Nutr Food Res 58: 457-465, 2014.

23. Hale LP, Greer PK, Trinh CT and Gottfried MR: Treatment with oral bromelain decreases colonic inflammation in the IL-10deficient murine model of inflammatory bowel disease. Clin Immunol 116: 135-142, 2005

24. Amini A, Masoumi-Moghaddam S, Ehteda A and Morris DL: Bromelain and $\mathrm{N}$-acetylcysteine inhibit proliferation and survival of gastrointestinal cancer cells in vitro: Significance of combination therapy. J Exp Clin Cancer Res 33: 92, 2014.

25. Pillai K, Ehteda A, Akhter J, Chua TC and Morris DL: Anticancer effect of bromelain with and without cisplatin or 5-FU on malignant peritoneal mesothelioma cells. Anticancer Drugs 25: 150-160, 2014.

26. Amini A, Ehteda A, Masoumi Moghaddam S, Akhter J, Pillai K and Morris DL: Cytotoxic effects of bromelain in human gastrointestinal carcinoma cell lines (MKN45, KATO-III, HT29-5F12, and HT29-5M21). Onco Targets Ther 6: 403-409, 2013.

27. da Silva CR, Oliveira MBN, Motta ES, de Almeida GS, Varanda LL, de Pádula M, Leitão AC and Caldeira-de-Araújo A: Gebxic and cytotoxic safety evaluation of papain (Carica papaya L.) using in vitro assays. J Biomed Biotechnol 2010: 197898, 2010.

28. Webman EJ, Edlin G and Mower HF: Free radical scavenging activity of papaya juice. Int J Radiat Biol 55: 347-351, 1989.

29. Mehdipour S, Yasa N, Dehghan G, Khorasani R, Mohammadirad A, Rahimi R and Abdollahi M: Antioxidant potentials of Iranian Carica papaya juice in vitro and in vivo are comparable to $\alpha$-tocopherol. Phytother Res 20: 591-594, 2006.

30. Oloyede OI: Chemical profile of unripe pulp of Carica papaya. Pak J Nutr 6: 379-381, 2005.
31. Zender S, Nickeleit I, Wuestefeld T, Sörensen I, Dauch D, Bozko P, El-Khatib M, Geffers R, Bektas H, Manns MP, et al: A critical role for notch signaling in the formation of cholangiocellular carcinomas. Cancer Cell 23: 784-795, 2013.

32. Karin M, Cao Y, Greten FR and Li ZW: NF-kappaB in cancer: From innocent bystander to major culprit. Nat Rev Cancer 2: 301-310, 2002.

33. Kalra N, Bhui K, Roy P, Srivastava S, George J, Prasad S and Shukla Y: Regulation of p53, nuclear factor kappaB and cyclooxygenase- 2 expression by bromelain through targeting mitogen-activated protein kinase pathway in mouse skin. Toxicol Appl Pharmacol 226: 30-37, 2008.

34. Bhui K, Prasad S, George J and Shukla Y: Bromelain inhibits COX-2 expression by blocking the activation of MAPK regulated NF-kappa B against skin tumor-initiation triggering mitochondrial death pathway. Cancer Lett 282: 167-176, 2009.

35. Mohr T and Desser L: Plant proteolytic enzyme papain abrogates angiogenic activation of human umbilical vein endothelial cells (HUVEC) in vitro. BMC Complement Altern Med 13: 231, 2013.

36. Gill LS: Ethnomedical uses of plants in Nigeria. Uniben Press, Benin, Nigeria, 1992.

37. Salminen A, Hyttinen JM and Kaarniranta K: AMP-activated protein kinase inhibits $\mathrm{NF}-\kappa \mathrm{B}$ signaling and inflammation: Impact on healthspan and lifespan. J Mol Med Berl 89: 667-676, 2011.

38. Guo Y, Zhang Y, Hong K, Luo F, Gu Q, Lu N and Bai A: AMPK inhibition blocks ROS-NFKB signaling and attenuates endotoxemia-induced liver injury. PLoS One: 9: e86881, 2014.

39. Franco-Chuaire ML, Magda Carolina SC and Chuaire-Noack L: Epithelial-mesenchymal transition (EMT): Principles and clinical impact in cancer therapy. Invest Clin 54: 186-205, 2013. 